\title{
Milking Partners or Symbiotic Know-How Enhancement? \\ International Versus National Alliances in Japan`s Biotech Industry
}

\section{Katrin Gassel, Werner Pascha *}

\section{Introduction}

It is frequently contended that as for research and development (R\&D), the scientific basis of innovation, Japan has been a freerider with respect to the international community. It is generally accepted, both within and outside the country, that, be that as it may, Japan as an important "frontier economy" can no longer rest on this position (e.g., cf. Ueda, 1996, p. 22). This paper is about one possible way out of this unsatisfactory situation, i.e. (research) alliances among companies, in order to complement their weak basis of scientific knowledge in one of the most advanced fields of scientific research and most promising fields of business interest: new biotechnology. With respect to such alliances, there is always the fear that "the game is not strictly played by the rules", i.e. that one "partner" will cheat - or at least will try to cheat - the other. Does this apply to Japan, particularly if foreign companies are involved: are partners "milked", or is there a symbiotic know-how enhancement, fruitful for all participants?

Alliances can be established with scientific institutions or other companies, among them potential competitors, at a national and/or an international level. As for national alliances, government-sponsored R\&D consortia can play a major role. How do these relationships work and what are their results? Surveying the relevant literature, several hypotheses can be put 
forward. With respect to international alliances, it is frequently suggested that an uncontrolled dissemination of technological know-how from the foreign to the Japanese partner may take place, which could be a major reason for failures of co-operative ventures. On the other hand, Japanese research consortia are often seen in Western literature as an effective tool of technology creation, because of the extensive potential information exchange (cf. Audretsch, 1988, 1989, Saxonhouse, 1985, 1986, Ouchi/Bolton, 1988). This reasoning suggests that the fruitful sharing and accumulation of information and technology is indeed possible - at least at the national level. How do these hypotheses bear out when confronted with empirical evidence from Japan's biotech industry?

\section{Definitions and Methodology}

\subsection{Definitions}

What does "biotechnology" mean and how are the terms "co-operation" and "alliances" defined in our paper? In Japan, the definition of biotechnology is usually used very broadly, not allowing for international comparisons. To ensure comparability, our paper is based on a common definition used world-wide referring to new biotechnology: it comprises recombinant technology (rDNA), cell fusion and novel bio processes (cf. OTA, 1984, p. 3). Older techniques, such as fermentation, in which Japanese firms possess substantial strengths (sake rice wine, miso soy sauce), are excluded from our investigation. It is important to realise that expertise in these older techniques does not automatically provide a comparative advantage in new biotechnology (cf. Shan/Hamilton, 1991, p. 421). It requires a completely new approach

\footnotetext{
${ }^{*}$ Prepared for the $8^{\text {th }}$ Triennial Conference of the European Association for Japanese Studies, Budapest, Hungary, 27-30 August, 1997.
} 
based on molecular biology. In this respect new biotechnology, i.e. rDNA technology, embodies a technological discontinuity which has to be overcome by firms.

New biotechnology as a generic technology (cf. OECD, 1989, p. 9) can influence a wide range of industries, such as chemicals, pharmaceuticals, food, agriculture, environment, etc. This makes it necessary to focus on particular industries, if the analysis is to be meaningful; we have chosen pharmaceuticals and agriculture for our research.

Pharmaceutical industry was selected, because it is the oldest and biggest segment of biotechnology markets (world-wide around 90\% in 1990), and many alliances between enterprises exist. In addition, the agricultural segment - referred to as agro business - was chosen, because it is a young and dynamic field, which could be of strategic importance for Japan: New biotechnology does not use up many natural resources and - when applied to agriculture - could help to overcome the Japanese dependence on foreign food imports (cf. Nihon Keizai Chôsa Kyôgikai, 1991, p. 111). In this context, it is noteworthy that biotechnology was chosen by the Japanese government as one of the three major advanced technologies (the other two being microelectronics and new materials) to be favoured by special promotion measures.

As for "co-operation" and "alliances", a wide range of definitions can be found in economics (cf. Rotering, 1990, pp. 38-41). For our research, dealing mainly with technological cooperation, we follow Pisano/Teece who "...define collaborative agreements in the context of innovation as any interorganizational (firm, university, government lab etc.) agreement, with or without equity, that involve the bilateral, multiparty, or unilateral contributions or exchange 
of assets or their services in the market." (Pisano/Teece, 1989, p. 228). We do not attach a different meaning to the term "alliance" here, but use it interchangeably1.

It may be useful to explain briefly why we use this rather wide definition: In order to see, how co-operation is made use of with different partners at a national and/or international level, it would not be opportune to exclude particular types of co-operation from our analysis, as long as they concern technology. Moreover, existing literature and databases would be difficult to use, if we narrowed down our analysis to a strict and limited understanding of co-operation.

\subsection{Methodology}

In order to gain results, a twofold empirical investigation was undertaken. On the one hand, a database containing world-wide alliances in biotechnology was explored. The "Actions Database" developed by the North Carolina Biotechnology Center (NCBC) deals exclusively with biotechnology alliances world-wide ${ }^{2}$. This database was primarily explored in extracting all alliances of Japanese firms at a national and international level from 1980 until 1995. The

\footnotetext{
${ }^{1}$ For a more elaborate discussion, see Pascha (1992).

2 The database contains information on more than 11,000 worldwide alliances (1996) in biotechnology, including 1,060 cases with Japanese participants. The alliances are classified according to legal aspects, such as joint ventures, research contracts, license agreements etc. Information is based on regularly screening more than 100 English language journals. With respect to the qualitiy of information in general and on Japan in particular, several points need to be taken into careful consideration: a) Japanese sources on Biotechnology (in Japanese language) have been used in 1989 only (Bio nenkan '88/`89). Newer entries refer completely to English language material. b) The content of Japanese cooperative efforts often cannot be identified exactly. This problem was solved by counting them as "joint ventures". This term comprises specified as well as unspecified joint action. c) The classification scheme was enlarged in the early 1990s. Older entries were not adjusted to the new scheme, so comparability is limited. d) As alliances tend to be very complex in some cases, it is difficult to classify them with appropriately. If, for example, a research contract is recorded, this may actually represent only one part of a more extensive relationship. The whole alliance may include license agreements and a minority shareholding as well. e) In the database, a broad definition of "biotechnology" is used. This increases the probability of misentries. For example, "old biotechnology"-related aspects may be recorded as well, making conclusions on new biotechnology more difficult (cf. Gassel, 1997, pp. 113-116). Despite these shortcomings, we decided to make use of this database. Other data sources have severe shortcomings as well (see ibid.). Since 1994, JETRO publishes a digest of Japanese international business alliances in English and, with more information on sources used, in Japanese. It started too recently, though, to be meaningful to our analysis.
} 
type of co-operation is reflected in these results, indicating the intensity of technological interaction.

On the other hand, 17 case studies about Japanese enterprises active in the field of biopharmaceuticals and/or agro business were conducted between 1994 and 1995 by one of the authors. The investigation was carried out by conducting semi-standardized interviews with research managers as well as by employing standardized questionnaires to be answered by these persons after the interview (cf. Gassel, 1997, pp. 178-180). In addition, two research consortia in the field of biotechnology were explored ${ }^{3}$ (cf. Haaf, 1996, pp.30-39). The cases provide more in-depth information going well beyond the limited scope of the database.

\section{Empirical evidence}

\subsection{General survey}

Biotechnology markets within the triad are supposed to account for 30-100 bio. (i.e. $10^{9}$ ) US\$ in 2000 (cf. Burrill/Roberts, 1992, p. 647, Kenward, 1992, p. 51, Dolata, 1993, p. 739, Ernst \& Young, 1994). As of present, the Japanese market is the second largest in the world, mainly represented by the pharmaceutical industry. According to one estimate, in $2000,20 \%$ of all drugs may be produced by employing biotechnological methods (cf. Sangyô Kenkyûjo, 1993, pp. 25-26). Japanese biotech industry, recently also called "DNA industries" (JBA, 1996, p. 2), differs significantly from its American and European counterparts: while the US industry is represented by many small high-tech firms called "new biotechnology firms" (NBF) (cf.

\footnotetext{
${ }^{3}$ For details see Haaf (1996, pp. 30-39).
} 
Sharp, 1990, p. 102, Arora/Gambardella, 1990, p. 361) ${ }^{4}$, and firms in Europe increasingly following the same pattern, biotech industry in Japan is characterised by large enterprises from different industries diversifying into new biotechnology (cf. Nakano/Tomita, 1990, pp. 79-82). The structure implies that there is a lack of highly specialised researchers having left university to become "scientific entrepreneurs" (cf. Teitelmann, 1991, p. 18) as is the case in the US and Europe.

How are these large enterprises active in biotechnology trying to strengthen their research and development basis in life sciences? Possibly, one way could be to look for alliances, which will be discussed now. Our results are presented in three sections: international (private industry) alliances, national (private industry) alliances, and national research consortia which are financed by the public to some extent. To start off with, though, a general outline of the development of collaborative agreements over 15 years will be presented.

According to the Actions Database, alliances of Japanese firms in the field of new biotechnology increased sharply around 1986/87 and peaked in 1988 (see fig. 1). Since then the amount of newly registered alliances has decreased continuously. This is also true for international and national alliances. It should be noted that this fact does not imply that the volume of activity has declined. Database information is only available for new endeavours, and it provides little or no information on their duration or changes in intensity. We can only conclude that - to the extent that the database is reliable - the rush for new alliances has subsided.

\subsection{International co-operation}

\footnotetext{
${ }^{4}$ Also, the term "dedicated biotechnology company" (DBC) is widely used (OTA, 1991, p. 3).
} 
New biotechnology firms (NBFs) located in the US form the major bulk of partners of Japanese enterprises and, to a minor extent, colleges and universities. ${ }^{5}$ Co-operation with European partners does exist to some extent, with the volume of new alliances having been relatively stable from 1984 until 1991. Here European NBFs as well as large pharmaceutical and chemical enterprises active in biotechnological research have been chosen as partners.

According to the Actions Database, in the 1980s the prevailing form of co-operation were licensing and marketing agreements, to a lesser extent minority shareholding. In the early 1990s, the latter remained important in addition to research contracts which increased significantly. These patterns could especially be observed in biopharmaceuticals, while in the field of agro business, it was joint ventures that rose in importance. What do these different kinds of co-operative agreements tell us about the direction of technological transfer? No conclusions can be drawn from the information so far at hand.

To address this question, the following empirical study about the co-operative behaviour of US NBFs conducted by the NCBC in 1992 and 1993 should serve as an example. In 1992, $77 \%$ of the 200 participating firms stated that until the early 1990 s, their activities had been a product import or a technology transfer from the US to Japan (cf. Dibner/Schwartz, 1992, p. 531). The flow in the opposite direction was supposed to be around $10 \%$ of this amount. (The figures concerning American-European deals were very similar.) The survey in 1993 revealed a decrease in technology transfer down to $61 \%$, while $25 \%$ were judged as bi-directional technology flow (cf. Bullock/Dibner, 1994, p. 399). These results indicate some change in

\footnotetext{
${ }^{5} \mathrm{~A}$ comparison with the European engagement in university alliances in the US shows that the involvement is much higher. While only 50 Japanese technology transfer alliances of this type were registered in 1992, there existed 450 such activities with respect to Europe (cf. Dibner/Stock/Greis, 1992, pp. 1535-1538).
} 
relationships: Recently, Japanese firms have tended to provide a certain amount of interesting technology themselves, whereas in former years they were solely dependent on US (and, to some extent, European) technology.

In order to gain more information about the intensity of these co-operative agreements, some case studies undertaken by one of the authors are sketched out below. Before doing so, however, we will present some aggregated data of all the cases studied, in order to be able to see the cases selected in perspective. What about the major motives for co-operating at an international level? Given 14 reasons to be judged on a Likert scale, ranging from -2 to +2 , the most important reason for co-operation was to reduce innovation time (1.5), followed by gaining access to complementary know-how related to products (1.4) and international technology (1.3). The first and second motive can be seen as an explanation for the sudden increase in licensing agreements in the mid 1980s between Japanese firms and US NBFs or European pharmaceutical firms respectively. The motives indicate an inclination by Japanese firms to gain access to available product or process technology through payment in an outright or a more indirect manner. Actually, this strategy follows a well known pattern and is to be found in other industries as well, such as electronics, for example.

Some empirical cases:

- The pharmaceutical firm Chugai entered biotechnology by acquiring a license for an Erythropoitine (EPO) production technology from the American NBF Genetics Institute. For EPO, Chugai conducted clinical trials in Japan and has been selling the product since 1990. In addition, Chugai acquired the NBF Gene-Probe in 1989, in order to realise firstmover advantages in selling diagnostical test kits in Japan. By taking over Gen Probe, a 
highly intensive relationship between a Japanese and an American partner was built up. Whether this should be judged as constituting a co-operation (covered by our definition) is open to further discussion.

- Green Cross, Japan's first commercial blood bank, in the early 1980s decided to engage in biotechnology. In-house research on rDNA failed, so that in 1989 the firm started an alliance with an American NBF active in the field of gene expression. Green Cross licensed-in the relevant technology and developed the product on its own. It will be on the market in 1998.

- Kyowa Hakko, a leading company in fermentation technology, entered new biotechnology in co-operation with Mitsubishi Chemical. In 1982, both firms acquired a license for a Tissue-Plasminogen-Activator (TPA) in order to separately develop the product for the Japanese market. The joint purchase aimed at reducing the registration costs as well as the monetary risks in case this new technology failed.

Whereas these cases cover activities since the 1980s, it was pointed out in several interviews that in the early 1990s the focus of interaction changed slightly: Japanese firms which, to start off with, licensed-in products (i.e. biopharmaceuticals), are now increasingly interested in gaining access to technology instead of products. These observations correspond to minor changes of co-operation modes: the database shows an increase in minority stakes and research contracts. The interviews revealed that these agreements were often concluded in a combined way, with the Japanese side investing in an international partner prior to signing a research contract inducing the partner to conduct research on behalf of the Japanese firm. 
Some empirical cases:

- In 1993, Chugai bought $8 \%$ of the shares of the Australian enterprise Amrad. It aimed at developing a haematological product for which Chugai concluded a research agreement for a 3-year period. In return, Chugai obtained the right to market the product in Japan, Taiwan, and South Korea.

- Eisai, the no. 4 in Japanese pharmaceuticals, invested in the American NBF GenPharm International in 1993. In addition, Eisai pays milestone-fees within a research agreement specifying certain research results. These payments (of up to 28 mill. US-\$) will give Eisai the right to produce and sell the product.

- Japan Tobacco (JT), Japan's sole tobacco producer, restructured its business activities in the 1980s, aiming at exploring new business opportunities. In 1986, JT entered into pharmaceuticals, the agro business, food and real estate. The bio focus was considered to supplement the inherent strength in old biotechnology and chemical synthesis, as new biotechnology is one technology pursued in the pharmaceutical and agro business segment. JT then founded an American subsidiary which entered into a joint venture with the NBF Cell Gynesis. JT is paying money to the joint venture which in return offers research contracts to Cell Gynesis. This structure was chosen in order to realise tax reliefs available for so-called "limited partnerships" (cf. Ullrich, 1988, p. 85). In 1994, the project was enlarged so that the new technologies created could be developed further up to include commercialisation. In agro business, JT follows the same strategy: It founded a subsidiary which established a joint venture with an American NBF. In addition, JT headquarters took a minority stake in NBF, which may be seen as a controlling move to ensure outstanding 
research efforts in the partnership. One of the first products to emerge from this partnership was planned to be sold in Japan in 1996.

In addition, several interview partners pointed out that recently they have headed for joint research and development agreements with a personnel input from the Japanese side. This corresponds to the fact that firms had been gaining strength in biotechnological procedures. The findings were not obvious from the database results. ${ }^{6}$ They primarily refer to biopharmaceuticals and to a lesser extent to agro business. The development is illustrated by some examples from our case studies.

Some empirical cases:

- In 1992, Kyowa Hakko entered a co-operation with an American NBF in order to do research and develop a low-molecular drug. This alliance is of high strategic importance for both partners, with Kyowa providing compounds which might be useful for drug development and the American firm selecting and evaluating these candidates using its own and screening systems of Kyowa Hakko. Drug production will be carried out by Kyowa Hakko, which will have the exclusive production and sales rights for Japan and Asia. The American partner will sell the product in the US. During the research and development phase, an intensive information exchange between researchers of both sides has taken place. Both parties seek to improve their technological skills within the collaboration.

\footnotetext{
${ }^{6} \mathrm{~A}$ reason for this discrepancy could be the complexity of the relationship. In case an agreement comprises a combination of licensing, a research contract and a joint development in later stages, possibly only one of these features has been published and is therefore included in the database (cf. Duysters/Hagedoorn, 1993, p. 1).
} 
- Yamanouchi also started an intensive alliance with an American NBF. Both partners are considered equal in their scientific contribution to the co-operation in that they have combined their respective libraries of chemical and biological compounds, in order to develop an anti-inflammatory drug. The project is characterised as basically researchoriented and researchers of both sides are involved in an intensive dialogue.

- $J T$ entered into an intensive agreement in the field of agro business. In 1989, it bought 8.7 $\%$ of the shares of the Belgium NBF Plant Genetic System (PGS) for a 7-year period of cooperation. The aim is to investigate prerequisites for developing a recombinant hybrid rice. In a later phase, the inclusion of other products, such as maize and potatoes, is planned. The scope of the co-operation is extremely broad and expenses for JT are estimated at around 200-300 mill. Yen. As part of this co-operation, PGS will have to identify genes appropriate to insert into the rice genome and to develop technologies for this insertion. JT will carry out the actual gene transfer and field trials and will modify the technology when necessary. The partners are combining their respective strengths, such as laboratory work at PGS and experimental work at JT, the latter being rooted in its tobacco growing business. The interviewee pointed out that at the beginning of the co-operation, JT was dependent on PGS, but in the course of time, JT became an equal partner. Today the relationship can be judged as a balanced partnership.

These examples show that firms having in-house specialists whose scientific level is comparable to that of its international partner, are basically willing to contribute substantially to an alliance in terms of making available the necessary technological expertise. Anyway, these cases are rare as the Japanese level of scientific knowledge is still comparatively low in the field of new biotechnology. 


\subsection{National co-operation}

\subsubsection{Overview}

Figure 1 indicates that despite the dominance of Japanese-international co-operation, national alliances do happen. The number of new alliances of this sort increased sharply in 1987, peaking in 1988, but decreasing since. These alliances can take place at a private level or involve public participation, they can come about between firms, with a research institute or university. The Actions Database records reveal that $32 \%$ of all national alliances are enterprise-university deals ${ }^{7}$, which are sometimes thought to be of rather limited importance in Japan. We will therefore take a closer look at them and, in addition, will discuss interfirm collaboration and research consortia.

\subsubsection{National interfirm co-operation}

Further investigation into the quantity of alliances indicates that the most common modes of private-level co-operation are licensing and marketing agreements as well as co-operative ventures, which when looked at closely turn out to be research consortia. In the early 90 s, acquisitions were gaining momentum, too.

How intensive are these relationships? Only a few firms active in national biotechnology cooperation could be identified in our empirical research, so information provided here is somewhat anecdotal, and one should be careful about generalisations. There are major reasons 
for co-operation, one being to gain access to complementary resources, such as distribution channels. This is especially important in the field of agro business which is comprised of firms from all kinds of industries that have diversified into agriculture without substantial biotechnological resources. The "access to distribution channels" motive is reflected in several acquisitions of small and medium agricultural enterprises and the purchase of minority stakes. Given the fact that acquisitions do not represent a "co-operation" in the narrow sense and that licensing agreements are arms-length-transactions, the "real" so-called "hands-oncollaboration" between private partners at a national level is quite rare.

\section{Empirical case:}

- Kirin Brewery, the biggest beer producer in Japan, entered biotechnology in the early 1980s. It has been active in both pharmaceuticals and agro Business. These business fields are considered to be related to beer brewing, as they are based on old biotechnology and agricultural techniques. Kirin aims at realising synergy effects of old and new technologies. In agro business, for instance, Kirin aims at gaining first-mover advantages by using innovative technologies. Kirin started co-operating with Tokita Seed, in order to develop a new brassica specie called senpôsai. Kirin conducted all laboratory research and Tokita screened and selected the hybrid cells viable for commercialisation. Since 1989, Kirin has held a minority stake in Tokita, aiming at gaining access to the distribution channels of Tokita. In 1986, Kirin established a joint venture with a big flower retailer in order to distribute two types of chrysanthemums developed in-house. (In addition, Kirin bought into a British chrysanthemum producer and a Dutch flower export company, in order to establish an overseas network of production and distribution facilities).

\footnotetext{
7 Of the remaining $68 \%$, more than half could not be specified, which substantially reduces the degree of
} 


\subsubsection{National research consortia}

A substantial amount of classifiable national alliances represent research consortia. They were mainly responsible for the increase of co-operative agreements in 1987. Who was responsible for initiating and financing these alliances? Since 1986, several ministries (Ministry of International Trade and Industry, MITI; Ministry of Health and Welfare, MHW; Ministry of Agriculture, Forestry and Fishery, MAFF) have founded public venture capital institutions which invest in national research consortia conducted as a joint-stock company. $70 \%$ are paid publicly, 30\% by the participants (cf. Haaf, 1996. pp. 17-29, Hilpert/Mayerhöfer, 1994, p. 14, Levy/Samuels, 1991, p. 133, Gotô, 1993, p. 90). ${ }^{8}$ These consortia operate mainly in the field of biotechnology. During the 1980s, these alliances aimed at developing basic technologies already available abroad, in order to strengthen the basis of knowledge of the participating firms. Since the early 1990s, the goals set for the projects have become more specific, and they are generally considered by international observers to be advanced and state-of-the-art. This fact is reflected, for instance, in the participation of Hofmann-La Roche in one case, the first foreign firm to become a lead company of a Japanese research consortium.

A key issue is how serious these endeavours really are. Are participants, i.e. those who have accumulated a substantial know-how in biotechnology, indeed willing to let actual or potential competitors have access to these resources?

information about partners and forms of alliances.

${ }^{8}$ These consortia differ from the usual, widely known "research associations", which receive less public funds. In addition, research associations are resolved after finishing the project, whereas "new style consortia" will continue as a leagal entity (JKTC brochure and references above). 
A 1991 survey, conducted by the Sômuchô (Prime Minister's Office) among 326 responding firms, indicated that the major reasons for firms participating lie in wishing to share the financial burden and to strengthen the firm's scientific base. $40 \%$ of respondents revealed though, that the ministry used "moral suasion" in order to make them participate in the project. Asked about what to improve, the points raised most often were the establishment of rules for ownership and the use of results (52\%) (cf. Sômuchô, 1992, pp. 339-341). These findings indicate the firms' concerns of having to share proprietary know-how and technology.

In our case studies, we explored the general attitude towards these new-style consortia. The answers differed according to the type of industry and competitive biotechnological strength of individual firms. Companies active in agro business preferred to participate in research where concrete results were likely to be achieved. The interviewees argued that their limited human and financial resources have to be used efficiently and with commercially viable results. This indicates that firms still consider themselves to be located in an early stage of the industry life-cycle. Pharmaceutical firms which see themselves as latecomers in biotechnology accepted to participate in a research consortium and hoped to improve their technological base, whereas firms in advanced competitive positions signalled that they were taking care about safeguarding their primary research focus. Overall, major motives for participating firms were burden-sharing and an intensive information exchange with respect to research personnel.

\section{Empirical case:}

- During the 1980 s a research consortium to develop secondary metabolites was financed by the Japan Key Technology Center, the venture capital institution of MITI and the Ministry 
of Post and Telecommunication (MPT). 70\% (2,8 bio. Yen) were provided by JKTC, 30\% by the participating firms for about 6 years. The project was characterised by basic and applied stages of research and development, which was obvious from the goal to develop technologies on an industrial scale. The 7 participants came from 4 different industries, such as the petroleum, food, electronics and chemical industry. The focus of their research also differed significantly: some of them aimed at generating techniques for agro business, others for pharmaceuticals or environment and medical equipment. Our interviewee - an administrative manager - pointed out that he was not able to talk about the real goals of the (other) participants because they refrained from revealing them. Research was conducted in separate laboratories located all over Japan, and the researchers met twice a year, in order to exchange results. The manager said that because these contacts were rare, researchers did not fear having to give insight into confidential know-how and technologies. The results generated within this co-operation were meagre: the technologies which should have been developed were not realised. The manager was of the opinion that the firms did not allocate sufficient resources to their respective part of the project. The firms were separately asked in a questionnaire about their motives for participation. Answering on a Likert scale, ranging from -2 to +2 , the major reason named was risk reduction (1.7), followed by accumulation of financial and human resources (1) and technological synergies (1.0). Information sharing was only considered partially important (0.5), a result not well in tune with our other interviews.

What do we learn from these results? Japanese firms seem to have at least an ambiguous attitude towards research consortia. Technology sharing and resource accumulation seem to be a likely possibility when firms are latecomers, but not when "first movers" with proprietary technologies are asked to participate. In such cases, national research consortia cannot 
reasonably be expected to contribute significantly to the improvement of scientific knowledge at the "frontier" of advanced biotechnology. It should be mentioned in passing that this result is well in tune with other recent, rather sceptical studies of Japanese high-tech government policy and of the role of national research consortia in particular (cf. Pascha 1995 for an appraisal, among many others).

In March 1997, all bureaucratic venture capital institutions temporarily stopped financing new consortia, because no consortium founded within the last 10 years had produced substantial results in the sense of it having led to appropriate returns of the money invested (cf. Asahi Shinbun, 1.3.1997). On the one hand, this decision could be interpreted as a confession of the inappropriateness of this tool for generating advanced technology among competitors. On the other hand, scarce results should not necessarily (only) be blamed on the instrument of publicly supported joint research efforts, because to some extent it may reflect the very nature of basic research, which is that commercial results are unpredictable.

\subsubsection{University-private sector co-operation}

We now turn to the relationship between industry and academia, represented by universities and public research institutes, whose role is signified by the Actions Database. The results indicate that one third of national alliances takes place between a Japanese firm and a national scientific institution. It could well be thought natural that biotechnology as a science-based technology requires strong ties between these partners in order to achieve outstanding results. Nevertheless it is somewhat surprising, because the level of basic life sciences in Japan is still weak compared to US and European levels as well as compared to other natural sciences in Japan (cf. Kagaku Gijutsuchô, 1994, pp. 370-371). Furthermore, Japanese firms are 
continuously complaining about the lack of strength of Japanese universities in basic science and about the insufficient level of co-operation between firms and universities, as a survey conducted by the Science and Technology Agency in 1990 revealed (cf. Asahi Shinbun, 20.11.1990). ${ }^{9}$ It can also easily be shown that researchers active in the field of biotechnology are rare in comparison to the United States, for instance. ${ }^{10}$ Taking these factors into account, why is the number of alliances between firms and academia so substantial?

Before we present our own findings, some related empirical studies will be quoted. In 1992, Hicks et al. showed, using a sample of 28 large Japanese enterprises, that the co-authorship between researchers of these firms and academic institutions increased by about $6 \%$ between 1984 and 1989. The number of publications in the field of life sciences increased more substantially though $(30 \%)$, and they were more basic than those from other scientific disciplines (cf. Hicks et al., 1994, pp. 375-384). These results point to quite a close and increasing co-operation between industry and science.

Further evidence in this direction is provided by a study by Fransman/Tanaka (1995), who tried to identify the relevance of Japanese universities for biotechnological activities of Japanese firms. Within a somewhat anecdotal sample of 6 leading enterprises in biotechnology, 4 pointed out that Japanese universities are the main source of their external technology transfer (out of 6 alternatives). The authors explain these findings by arguing that the partners tend to develop commercial applications from results generated by the firms themselves, whereas university ties are an important means to recruit scientific personnel

\footnotetext{
${ }^{9}$ Out of the sample of 300 R\&D managers, 211 persons answered the survey questionnaire.

${ }^{10}$ Whereas in the US, the number of bio-researchers is 37,000, the equivalent for Japan is 8,500 (Japaninfo, 1.7.1996).
} 
recommended and mediated by a professor (cf. Fransman/Tanaka, 1995, pp. 43-48; for a similar point made, see Fujiwara, 1992).

Our case studies led to a somewhat different result, although we have to admit that our sample was quite limited and that generalisation may be inappropriate. Nevertheless, two enterprises were convinced that ties with universities (at a national level) lead to interesting and important results, which may turn out to be marketable; 11 enterprises had been conducting diverse projects with universities, which seemed to be at least of some scientific importance. The remaining firms were also involved in some kind of relationship, but pointed out that the main objective of the projects was to establish relationships with professors. All interviews had one thing in common: the interviewees were not willing to discuss details about the relevance of on-going projects. The conclusion to be drawn from this attitude could well be that university ties in Japan may be of bigger importance than is generally believed in the West.

\section{Results: Does co-operation matter - and how?}

Japan's biotech market is supposed to be the second largest in the world - indicating vibrant industrial activity. Firms active in the field are mostly large, established enterprises which diversified into biotechnology in the 1980s. Some of them possess considerable strength in old biotechnology and pursue new biotechnology as a seemingly logical consequence, although transferability of know-how from the first to the latter may be quite limited. Others do not have such a background and have tried to open up new business opportunities, hopefully leading to interesting new products with a high value-added and profit potential, such as pharmaceuticals and new agricultural species. Firms reaching out for biotechnological 
expertise most often have to refer to external sources of technology. That is why in Japan's biotech industry, various types of co-operation play an important role.

At an international level, and returning to the title of this paper, the key question is to what extent and how far the companies are committed to such "alliances". Are they trying to merely use them to "milk their partner", i.e. trying to gain as much technological expertise as possible from the foreign "partner", while at the same time hiding their own expertise and progress as effectively as possible, or is there a chance for a "balanced", symbiotic know-how exchange and enhancement among partners?

During the 1980s, when international licensing-in of technology and products were of prevailing interest, little interaction of the partners took place; in a narrow sense, Japanese firms indeed tried to "milk their (international) partner" in terms of one-sidedly gaining access to their technology. However, this statement is somewhat unfair, because the foreign partners got something in return, i.e. licence fees. It should be noted in this context that during that period, especially American NBFs were eagerly seeking financial resources to continue their promising research - and got the money from Japanese partners: $60 \%$ of all deals between NBFs and Japanese firms were initiated by the American partner after all (cf. Longman, 1992, p. 38; Nikkei Weekly, 1.8.1994). Both sides got what they needed - technology for cash and vice versa.

It is challenging to consider whether Western partners fell into a trap by following such a strategy. After all, it would not have been the first time that Japanese companies licensed-in know-how, built upon it and later became successful competitors, driving their former "teachers" out of the market. The scope of our study is too limited to develop a convincing 
argument in this respect, though. We can only offer a few insights here which would be part of a more encompassing analysis not available yet: (a) what Western partners got in return for supplying licences, were - in many cases - significant strategic assets, i.e. financial funds, which were difficult to get otherwise for an upstart venture company. (b) At least until the mid 90s, Japanese biotech industry had still not become a "formidable" competitor, in the sense of seriously driving out the business opportunities for enterprises abroad; one reason possibly is that new biotech offers many different business opportunities, (often) with few economies of scale, so there is little fear of "crowding-out" at this early stage of market development. (c) Finally, one should not overestimate the extent of a one-sided West-East technology transfer. If one compares this flow to other activities within the triad, one finds that a bigger share is both transferred within the U.S. or flows (from the US) to Europe (cf. Dibner/White, 1989, Bullock/Dibner, 1994).

In recent times, anecdotal evidence is discernible pointing towards an increased commitment of Japanese partners in international alliances. With an ongoing accumulation of expertise, they seem able and willing to pursue longer-lasting, flexible and trustful relationships with foreign partners. This indicates that there may well be the possibility of a fruitful and symbiotic know-how enhancement, something which should be taken into consideration when fears are voiced about a "technological hollowing-out" of the Western biotechnology industry.

At a national level, a somewhat reverse development seems to take place: With private cooperation hardly occurring at all, Japanese firms also refrain from providing access to internal scientific resources within research consortia. The more advanced their technological base, the more they regard government-sponsored research consortia as a "national necessity", in which they just have to participate - and from which they may be able to reap at least some benefits -, 
but to which major commitments should be avoided. This is a distinct indication for an inclination towards "milking partners" - i.e. "milking" the government in terms of gaining access to public funds, and other companies in terms of gaining valuable R\&D information (future trends, strengths and weaknesses of competitors, etc.). In contrast, industry-university ties seem to be fruitful and symbiotic in the limited sense that these activities are an interactive give and take between professors mediating between research personnel and the firms that finance the projects promoted and carried through by academics.

As a final question, let us discuss whether our findings are consistent, particularly with respect to our thesis that, at an international level, there is some indication that Japanese biotech firms are developing into trustworthy partners for a mutual know-how exchange, whereas at a national level, no such evidence could be found. The following two points are meant to show why we consider these statements not to be contradictory:

- Government-sponsored consortia have frequently been set up in Japan to help the laggards. Contrary to popular belief, this is a continuous underlying interest of public policy in Japan. It follows that those with some competitive strengths are unwilling to commit themselves wholeheartedly. Gone are the days when the government could enforce such type of behaviour in favour of the marginal enterprises in a given industry.

- At an international level, Japanese companies may have become aware of the fact that for a continuous and fruitful relationship with a leading-edge company to develop, a trustworthy relationship is required. With so many different substances and niches in biotechnology, to cheat a partner, for example, with respect to a promising drug would simply mean losing him (and possibly others as well) for other, mutually profitable endeavours. 
Of course, the foreign partner has to be careful. At the national level evidence suggests that Japanese biotech companies do not possess "saintly qualities". This is not to be expected anyhow, and an international partner - as always - should make sure that alliances with a (here: Japanese) partner are carefully planned and operated to avoid unfair practices ("shirking"); surely, there are several, well documented ways and means available for implementing an "optimistic, but hedged" strategy (holding "hostages", information channelling, etc.), which any well-managed company should be able to make use of. Given such care, however, there is great potential for co-operation.

\section{References}

Asahi Shinbun (20.11.1990) Kiso kenkyû ya jinzai kakuho ga kadai (Maintenance of human potential and basic science as task).

Asahi Shinbun (1.3.1997) NTT kabu haitô, haibun minaoshi (The allocation of NTT shares dividends will be revised).

Audretsch, D. B. (1988) Eine Evaluation der japanischen FuE- und Industriepolitik, Diskussionspapier FS IV 88-8, Wissenschaftszentrum Berlin, (German translation of "An evaluation of Japanese R\&D and Industrial Policies. Außenwirtschaft, 43.Jg., Heft I/II, pp. 103-125). 
Audretsch, D. B. (1989) Joint R\&D and Industrial Policy in Japan, in Link, A.N. and Tassey, G. (Eds.): Cooperative Research and Development: The Industry-University-Government Relationship, Dordrecht, pp. 103-125.

Bullock, W. and Dibner, M. (1994) The changing dynamics of strategic alliances between US biotechnology firms and Japanese corporations and universities. Trends in biotechnology, Vol. 12, No. 10, pp. 397-400.

Burrill, S. and Roberts, W. J. (1992) Biotechnology and Economic Development: the Winning Formula, in: Bio/Technology, Vol. 10, pp. 647-653.

Dibner, M. and Schwartz, R. (1992) International Strategic Alliances. Bio/Technology, Vol. 10 , pp. 528-533.

Dibner, M. and Stock, G. and Greis, N. (1992) Away from home: US-sites of European and Japanese Biotech R\&D. Bio/Technology, Vol. 10, pp. 1535-1538.

Dibner, M. and White, S. R. (1989) Biotechnology Japan, New York.

Dolata, U. (1993) Nischen- oder Schlüsseltechnologie?. WSI Mitteilungen 11, pp. 736-746.

Duysters, Geert/Hagedoorn, John (1993). The cooperative agreements and technology indicators (CATI) information system, mimeo., MERIT, Maastricht (unpublished) 
Ernst \&Young (1994). Biotech '95. Reform, Restructure, Renewal, The Ernst \& Young`s Ninth Report on Biotechnology Industry, Palo Alto.

Fransman, M. and Tanaka, S. (1995) Government, globalisation, and universities in Japanese biotechnology. Research Policy, 25, pp. 13-49.

Gassel, K. (1997) Kooperationen japanischer Unternehmen in der neuen Biotechnologie staatliche Rahmenbedingungen und privatwirtschaftliche Initiative, PhD.-thesis, Department of Economics, Duisburg University.

Gotô, A. (1993) Nihon no gijutsu kakushin to sangyô soshiki (Innovation and Industrial Organisation in Japan), Tôkyô.

Haaf, K. (1996) Japanische Forschungskonsortien am Beispiel der neuen Biotechnologie, Duisburg Working Papers On East Asian Economic Studies, No. 26, Duisburg University.

Hicks, D. et al. (1994) Japanese corporations, scientific research and globalization. Research Policy, 23, pp. 375-384.

Hilpert, H. G. and Mayerhöfer, M. (1994) Das Japan Key Technology Center und die New Energy Industrial Technology Development Organization - Institutionen zur Förderung von Grundlagentechnologien in Japan. Japan. Analysen, Prognosen, ifo Japan Studienstelle, No. 94, pp. 7-32. 
Japaninfo (1.7.1996) "Japan steht weit hinter der US-Biotech-Forschung", 17. Jg., No. 9, pp. $17-18$.

Japan Key Technology Center (n.d.) The Japan Key Technology Center, Tôkyô, without year.

JBA (Japan Bioindustry Association) (1996) Japan Bioindustry Letters by JBA, Vol 13, No.2.

Kagaku Gijutsuchô (ed.) (1994) Kagaku Gijutsu Hakusho Heisei 6 nenpan....ima, sekai no naka de...., (White Book on Science and Technology, ...now, within the world...), Tôkyô.

Kenward, M. (1992) Biotech heads for the Big time. International Management, pp. 48-51.

Levy, J. and Samuels, R. (1991) Institutions and Innovation. Research collaboration as technology strategy in Japan, in Lynn Krieger Mytelka (Ed.), Strategic Partnerships: States, Firms and International Competition, London, pp. 120-148.

Longman, R. (1992) Japanese-American Biotech Deals. Venture Japan, Vol. 3, No. 4, pp. 3843.

Nakano, M. and Tomita, M. (1990) Baio gyôkai (Bio-Business Circles), Sangyôkai Shiriizu (Serial Business Circles) 619, Tôkyô.

Nihon Keizai Chôsa Kyôgikai (1991) Kagaku gijutsu seisaku no kokusaiteki tenkai - gijutsu no kokusaiteki izon kankei no fukumari wo fumaete (The development of an international 
technology policy - claiming the progress of international technological interdependence), Chôsa Hôkoku 91-4, Tôkyô.

Nikkei Weekly (1.8.1994) U.S.-biotech start-ups seek investment partners.

OECD (Organisation for Economic Co-operation and Development) (1989) Biotechnology. Economic and Wider Impacts, Paris.

OTA (Office of Technology Assessment) (1984) Commercial biotechnology. An international analysis, Congress of the United States, Washington D.C.

OTA (Office of Technology Assessment) (1991) Biotechnology in a Global Economy, Congress of the United States, Washington D.C.

Ouchi, W. G. and Bolton, M. K (1988) The Logic of Joint Research and Development. California Management Review, pp. 9-33.

Pascha, W. (1992) Strategische Allianzen mit japanischen Firmen - eine innovative Lösung oder ein neues Problem, Teil I + II. Japaninfo, 13. Jg., Nr. 16 + Nr. 17.

Pascha, W. (1995) Forschungs- und Technologiepolitik in Japan: Die Wirksamkeit ist umstritten. Forschung \& Lehre, Mitteilungen des Deutschen Hochschulverbandes, 7, pp. 368379. 
Pisano, G. and Teece, D. (1989) Collaborative Arrangements and Global Technology Strategy: Some Evidence from the Telecommunications Equipment Industry. Research on Technological Innovation, Management and Policy, Vol. 4, pp. 227-256.

Rotering, C. (1990) Forschungs- und Entwicklungskooperationen zwischen Unternehmen, Serial Management von Forschung, Entwicklung und Innovation, No. 4, Stuttgart.

Sangyô Kenkyûjo (1993) Baiotekunorojii no saikin no dôkô ni kan-suru chôsa kenkŷu - Aratanaru baioindasutorii no hiyaku no tame ni (Investigation into new trends in biotechnologyFor an upswing of a renewed bioindustry), Sangyô Kôzô no Chôsa Kenkyû 4-3, Study conducted on behalf of the Japan Bioindustry Association, Tôkyô.

Saxonhouse, G. (1985) Japanese Cooperative R\&D-Ventures. A Market Evaluation, Research Seminar in International Economics, Discussion Paper No. 165.

Shan, W. and Hamilton, W. F. (1991) Country-specific advantage and international cooperation. Strategic Management Journal, Vol. 12, pp. 419-432.

Sômuchô (1992): Kagaku gijutsu gyôsei no genjô to mondaiten. Sômuchô no gyôsei kansa kekka kara mite (Current situation and problems in administrating science and technology from the Prime Minister`s Office`s point of view), Tôkyô.

Teitelmann, R. (1991) Miracles and Money: The Evolution of a New Industry, in R. Dana Ono (Ed.), The Business of Biotechnology. From the Bench to the Street, Boston, pp. 1-22. 
Ueda, T. (1996) The "Ideas" Budget. Look Japan, Vol. 42, No. 481, pp. 22-23.

Ullrich, H. (1988) Kooperative Forschung und Kartellrecht. Zeitschrift für das gesamte Handelsrecht und Wirtschaftsrecht, Beihefte, No. 61, Heidelberg. 